\title{
Students' Ability to Pose a Problem: The Case of Waste
}

\author{
Ifigenia Iliopoulou $1 *$ \\ ${ }^{1}$ Department of Special Education University of Thessaly, GREECE \\ *Corresponding Author: ifiliop@uth.gr \\ Citation: Iliopoulou, I. (2019). Students' Ability to Pose a Problem: The Case of Waste. Pedagogical Research, \\ 4(2), em0033. https://doi.org/10.29333/pr/5783
}

Published: May 15, 2019

\begin{abstract}
The present paper reports on the abilities of young students to pose a problem and explores how these abilities relate to the solutions suggested as well as whether the age of the student influences these abilities. Specifically, twenty-seven 6-year-olds and thirty 9-year-olds from two state schools located in Volos, a small provincial town in Greece, were used as a sample. The inductive analysis of the data, collected in the form of drawings and interviews indicated that the majority of the students were able to pose the problem; albeit in an incomplete way. According to them, the problem of waste is created when people discard whatever is not useful to them. Few of them connected the waste issue to consumption or were aware of the possibility of reusing or recycling. Even fewer students suggested solutions other than just throwing waste into a bin. The results showed that those students, who knew about reusing and recycling at the posing phase, suggested them as ways of reducing waste. It may be assumed that focusing more on improving the way students pose the problem could affect their suggestions for addressing it. It was also noted that thirdgraders seemed better able to pose the problem than younger students.
\end{abstract}

Keywords: problem-posing, waste, citizenship

\section{INTRODUCTION}

It is widely acknowledged that contemporary societies need to deal with serious environmental problems. A problem is defined as a matter or situation that needs to be dealt with. It requires a solution, which may or may not be immediately evident. Specifically, environmental problems are:
natural resource-based conflicts (which) arise not only from divergent ideas regarding appropriate uses of the environment and resources but also from different conceptualizations of the environment and the human - environment relationship. These conflicts frame understandings of both causation and potential solutions. The problem with problem definition emerges when no consensus exists regarding what constitutes management's problem definition (Ebbin 2011, 148).

Thus, every civilised society must ensure a safe and healthy way of living, characterised by social justice, equality, a healthy environment and manageable resources not only for its populace but for future generations as well. In other words, every society has an obligation to sustain and improve living conditions and to strive to address environmental problems. It must endeavour to enhance citizenship education from early childhood; meaning to enhance the sense of responsibility students should foster in order to become active citizens. This education will equip young people with the ability to make their own decisions and take responsibility for their own lives and 
communities, which will ultimately lead to more sustainable societies. Citizenship education refers to educating students in recognising, analysing and investigating problems in their communities (UNESCO, 1998; 2010).

It must be stressed here, that there are two types of problems: those that are considered to be well defined and those that are considered to be ill-defined. Well- defined problems have a clear solution based on evidence, facts and information. Whereas ill-defined problems are less likely to be identified because of the fact that there is no straightforward problem statement, thus leaving the interpretation of the problem up to the problem solver. This is somewhat challenging and in order to develop a problem-solving strategy, the problem solver must firstly set down clear aims, as their goal must be clear (Pretz, Naples and Sternberg, 2003, 4). "The real difficulty in solving an illdefined problem is in clarifying the nature of the problem: how broad it is, what the goal is, and so on and the representation of it as well" (Pretz et al. 2003, 8).

Pruneau and her colleagues (2003) found that beginners tend to move too fast towards a solution, a concrete environmental action; failing to give adequate attention to the problem-posing stage. Experts, however, focus more on the problem posing stage itself. According to Cankoy and Darbaz (2010), students will be unable to come up with appropriate strategies for dealing with a problem if they are unable to comprehend the problem itself. They will be unable to explain their actions and the reasons for them (relational understanding) and a loss in motivation to find a solution to the problem will ensue.

According to many researchers in the field of mathematics education, the process of problem posing positively affects problem-solving capability (Arikan and Unal, 2015; Cai, 1998; Cai and Hwang, 2002; Cankoy and Darbaz, 2010; Crespo, 2003; Ellerton, 1986; English, 1997; Grundmeier, 2003; Yaman and Dede, 2005; Leung and Silver, 1997; Levav-Waynberg and Leikin, 2009; Pittalis et al., 2004; Silver and Cai, 1996; Verschaffel et al., 2009). Yet, there is a scarcity of research on this issue. This is true especially in the field of environmental education where the ability students have to pose environmental problems has not been documented by many researchers.

Considering the above, the present study aims to explore the ability students have to pose a problem and how this ability may relate to the solutions they suggest for addressing the problem of waste. Furthermore, it aims to identify possible differences between two different age groups concerning their ability to pose problems. The ultimate goal is to be instrumental in providing a greater understanding of curriculum preparation and more successful instructional design with regard to Education for Sustainability.

\section{RESEARCH REVIEW}

Problem-posing strategies have been examined by some researchers (Brown and Walter, 2005; Stoyanova and Ellerton, 1996) in Arikan and Unal 2015). Several prior research studies provided evidence that students' ability to pose a problem influences positively their ability to solve problems (e.g., Arikan and Unal, 2015; Cai and Hwang, 2002; Cai, 1998; Crespo, 2003; Ellerton, 1986; English, 1997; Pittalis et al., 2004; Silver and Cai, 1996; Verschaffel et al., 2009).

Also, Barbier, Freiman, Pruneau, and Langis (2010) and Pruneau, Freiman, Barbier, and Langis (2009) used questionnaires and interviews to conduct an action research. Specifically, they observed the ability of Grade 3 students, before and after the use of representational tools, to pose the problem of sedimentation in a local river and provide solutions. Though ill-defined, results indicated that environmental problems could be dealt with by young students, who were able to make coherent representations as well as provide better solutions. To be more precise, students altered their less scientific notions and succeeded in improving their ability to pose the problem thanks to ideas provided by their friends. Representation and problem-solving strategies are suggested as a way to improve children's capacity to better pose a problem.

Barbier and his colleagues (2007) looked at the way sixth graders posed the environmental problem of pollution caused by traffic after a four month period involving interventions both in the classroom and in field work. The results highlighted the fact that students, unlike the experts, disregarded problem details such as causes, in favour of focusing on the problem itself and the impact it has. The students proved to be able to create only limited cause and effect connection networks as each of them individually was scarcely able to consider every aspect of such a complex issue. The students found difficulty in constructing a sentence describing the problem and providing an expedient outcome. This could be put down to the complexity of environmental problems being difficult to convey in just one sentence. The same result emerged from Pruneau and her colleagues' study (2001), which showed that the sentences formulated by students in order to describe the problem were incomplete.

Furthermore, the study gave insight into the personal motivation of students to participate in problem-solving actions. It revealed that their motivation was determined by their feelings as to whether or not their input would make a difference. Some solutions presented by the sixth graders were found to be adequate, others unrealistic, unoriginal and somewhat expected, ie.: 'not to do this', 'to prevent a cause'. One notable result is that students did not connect the traffic problems to human actions nor did they allude to their own involvement or responsibility. Indeed, they commented on the fact that 'other people should stop doing this or that'. 
Research into problem-solving has yet to reveal a great deal about the processes involved in the recognition, definition and representation of problems. In fact, it is the latter stages of problem-solving that have been the main focus of interest in research being carried out. However, it is the earlier stages that are of great importance if accurate and effective problem solving is to ensue; especially in the case of ill-defined problems (Pretz et al., 2003).

\section{THEORETICAL PERSPECTIVE}

Problem posing is chosen to be the theoretical framework of the present study. Problem posing has been identified by some distinguished leaders in mathematics and mathematics education, as an important aspect of mathematics education (e.g., Polya, 1957). Problem-posing constitutes one of the eight steps to problem-solving. Psychologists have described the problem-solving process as a cyclical process (Bransford and Stein, 1993; Hayes, 1989; Sternberg, 1986) usually consisting of eight principal operations: recognizing or identifying a problem; posing a problem (defining and representing it mentally); developing a solution strategy; assessing and choosing solutions (having organised their knowledge about the problem); planning the action; acting; evaluating the action, and then experiencing the process (Pretz et al., 2003).

In the planning phase of problem-solving, it is the processes of recognition, definition and representation that are used. Problem definition refers to stating the scope and aims of the problem clearly. Problem representation relates to the way in which the information concerning the problem is organised mentally. Mental representations comprise four areas: an account of the problem, an outline of aim, a set of approved operators, and a number of constraints. Remembering information in the form of a mental representation allows the problem-solver to memorise chunks of information, which allows for easier organization of the conditions and rules pertaining to a problem and which then enables them to determine which strategies would be useful in a given situation. It also facilitates in assessing progress towards accomplishing aims (Ellis and Siegler, 1994; Kotovsky, Hayes and Simon, 1985). A problem can be represented in various ways; verbally or visually (Pretz et al. 2003).

'Problem-posing education' is a term coined by the Brazilian educator Paulo Freire (1970) as an alternative to 'banking education' and is supported by educators such as McLaren and Giroux. It is this philosophy of problemposing education that is the bedrock of modern critical pedagogy. Problem-posing education recognizes that knowledge is not passed on by the teacher to the student but is built up through discourse between the two.

When students approach a new situation, they are asked to pose the problem. Posing a problem involves formulating it in order to better solve it (English, 1997). Knowledge that is the result of experience will influence students' ability to define and represent a problem. Indeed, if that problem is not in line with their suppositions, they may not become aware of its existence. In order for students to detect a problem, they must be acquainted with all relevant information in a given situation. Students will then be able to interpret the problem in their own words as they will have rearranged the information they have in order to better understand it and in doing so will be able to provide obstacles as well as goals to achieve (Stoyanova, 2000). Problem-posing necessitates the research and understanding of relevant information so as to be able to build a mental or visual picture of the given problem (Proulx, 1999 in Pruneau et al., 2009). Problem-posing entails the generation of a new problem or reformulation of a problem from given situations or problems (English, 1997; Grundmeier, 2003; Silver, 1997; Stickles, 2006). For a student to be able to pose a problem he must have the ability to: use his existing knowledge, draw parallels, reflect, communicate concepts, monitor, investigate, assess, visualise (Hauslein and Smith, 1994), choose words to describe the situation as it is and outline the desired situation (Jones, 1995), as well as to formulate the problem in one sentence (English, 1997; Michalko, 1991).

Being inherently motivated and open-minded are valuable in the process of problem formulation. Indeed, a crucial element in determining whether or not a student discovers or develops a novel solution to a problem is that individual's reason to find it and work towards generating both a definition and representation of the issue. These traits reflect a constant metacognitive attentiveness to the environment and the process of problem-solving. Lastly, the social context may also encourage students to become aware of existing problems and think divergently regarding solutions. Should the environment fail to motivate students to search for and investigate problems, they will remain unaware of the gaps in their understanding; they will not learn to consider ideas, nor will they be able to evaluate points of view. The stage of problem formulation hinges more on disposition and social context in contrast to the later stages of problem-solving. Regrettably, little experiential research has focused on these topics. (Pretz et al., 2003).

Students can be helped to become better at problem posing in four significant ways: encouraging them to scrutinize all problems by asking questions (Where? When? How? Who? How much? Why?); aiding them in research and the collection of data pertaining to the problem; providing them with the opportunity to create a visual representation of the problem; and having them consider each other's ways of posing the problem (www.pjse.ca). 
The process of posing a problem can be repeated throughout the solving process. The way a student represents a problem may change (Polya, 1957). Initially, students' representations are frequently incomplete so knowing how to collect data, analyse problems and try out solutions aid the students in improving their representations. Being able to return to one's initial representation may also enable the student to effect a more successful solution to a problem if the solution they had come up with fails to meet expectations. Green (1993) states the need for problems to be examined: visually (Heuristics can be used with the help of pictures, diagrams, illustrations), verbally (with words, sounds, sentences), digitally (with numbers to specify the extent or importance of the problem), sequentially (with representation of development stages), conceptually (with the help of symbols, theories, and analogies), and emotionally (expressing feelings regarding the situation).

Another important intellectual action related to problem posing is the formulation of the problem in one sentence (English, 1997; Polya, 1988). This ability aids in the search for a solution by making connections between the different elements of a problem namely: causes, impacts, obstacles, etc. and also links existing background knowledge with newly acquired information (Gregg, 1997). In other words, the students must also be able to use various efficient heuristics (Hayes, 1989). Heuristics include varied external representations in visual, textual, or symbolic forms and allow for the visualizing of important points relating to the problem (the initial stage); links between ideas; actions to be executed as well as possible limitations in these actions; goals to be reached, and the personal implications of the problem (Elias, Branden-Muller and Sayette, 1991).

\section{THE METHODS OF THE STUDY}

The purpose of the present paper is to explore the abilities of 6- and 9-year-olds to pose a problem and how this relates to their suggested solutions. After careful scrutiny of the curricula regarding Environmental Study in Greek kindergarten and primary schools (first to third grade) and examination of both students' and teachers' books, it is obvious that when referring to the problem of waste, the main focus is on the problem-solving process (Iliopoulou, 2016, 2018) and not on the problem posing process.

The specific issue of waste was selected because it constitutes a serious environmental problem which students experience in their daily life and which is included in the curricula of Greek kindergarten and primary schools (DEPPS, 2003a, 2003b).

It is obvious that no systematic teaching of the waste issue takes place from kindergarten to third grade. The emphasis is either only on recycling (Kindergarten) or only on some dimensions of the issue, such as the effects and solutions, without reference to the causes, understanding the waste concept or the personal contribution of students in creating and reducing the waste (Table 1).

The research reported in this paper was guided by three questions:

1. "How do students pose the environmental issue of waste?"

2. "How do their methods of problem posing relate to their suggestions?" and

3. "How do the two age groups' abilities of problem posing differ?"

Although the overall research explored the students' conceptions about all key dimensions (definition, causes, effects, collective, and personal solutions) of the waste, this paper responds to the three main questions cited above (Iliopoulou, 2011). The research reported herein provides results of one part of the study aimed at exploring: (a) the abilities of young children (6- and 9-year-old) to pose the waste problem; (b) whether these abilities relate to the solutions they suggest for addressing the problem; and (c) whether these abilities are different due to the age of the children. A review of relevant literature reveals that students possess the capability to pose environmental problems correctly and to come up with potential solutions. Nevertheless, this process must be encouraged in a progressive manner and necessitates much effort on their part. 
Table 1. Objectives and pertinent activities discussed in the curricula

\begin{tabular}{|c|c|c|}
\hline Waste & Objectives & Activities \\
\hline $\begin{array}{l}\text { Environmental } \\
\text { Education } \\
\text { programs }\end{array}$ & $\begin{array}{l}\text { To record the sorts of } \\
\text { waste created and to learn about waste management that protects } \\
\text { the environment. } \\
\text { To learn about modern methods of } \\
\text { waste management. } \\
\text { To reflect on the causes and } \\
\text { the risks arising from } \\
\text { the ineffective management of waste. } \\
\text { To realize the environmental and economic value of recycling. } \\
\text { To realize that cleanliness at school, } \\
\text { in the neighbourhood and the surrounding area is a matter of } \\
\text { individual responsibility and } \\
\text { social duty. }\end{array}$ & \\
\hline Kindergarten & $\begin{array}{l}\text { To recognise the products that can be recycled and reused. } \\
\text { To realise the significance of recycling and reusing in waste } \\
\text { reduction. }\end{array}$ & $\begin{array}{l}\text { Participate in local recycling programmes, } \\
\text { construct and place recycling bins at school and } \\
\text { create objects out of scrap materials (DEPPS, 2001) }\end{array}$ \\
\hline A grade & $\begin{array}{l}\text { To know and be aware of methods of waste management. } \\
\text { To formulate rules to be applied to domestic and social life in } \\
\text { relation to environmental protection, such as to engage the } \\
\text { members of their family in activities relating to waste (separation, } \\
\text { reduction of waste, recycling). }\end{array}$ & $\begin{array}{l}\text { what would they say to a classmate who threw litter } \\
\text { on the ground (Plakitsi, etc., 2006a, p.20) } \\
\text { Discuss what human activities eg. people leaving } \\
\text { their rubbish on the beach, can cause to their } \\
\text { environment (Plakitsi, etc., 2006b, p.27). } \\
\text { How the family takes care of the environment in } \\
\text { response to the image of a child discarding litter on } \\
\text { the beach (Plakitsi, etc., 2006a, p.31). }\end{array}$ \\
\hline B grade & $\begin{array}{l}\text { To familiarize children with ways to reduce waste, such as recycling } \\
\text { and to raise awareness concerning environmental cleanliness issues. } \\
\text { To explore the journey of waste from the bucket to the dump. } \\
\text { To look for ways to reduce waste, such as changing their consumer } \\
\text { habits. } \\
\text { To recycle and reuse (Dimopoulos, etc., 2006b, p.89). }\end{array}$ & $\begin{array}{l}\text { Look at a picture depicting an old toy and ask } \\
\text { students what they do with their old toys } \\
\text { (Dimopoulos, etc., 2006a, p.106). } \\
\text { The teacher may motivate children to participate in } \\
\text { an activity related to waste and to separate the } \\
\text { waste at home and at school. }\end{array}$ \\
\hline$\overline{C \text { grade }}$ & $\begin{array}{l}\text { To investigate and present their proposals for dealing with rubbish } \\
\text { generated in the classroom (Kokkotas, etc., 2006, p.37). }\end{array}$ & $\begin{array}{l}\text { Children are asked: What can be done to minimise } \\
\text { rubbish? Have you heard of the word "recycling"? } \\
\text { What materials constitute the rubbish in our bins? }\end{array}$ \\
\hline
\end{tabular}

\section{The Context of the Study}

Those participating in this study are mainly from an urban environment and attend schools located in a small city. They were selected on the basis of them attending public sector schools in a mixed catchment area and with a diverse socio-economic student body. Convenience sampling was used in the selection of participants. The students were easy to recruit, and the researcher did not consider selecting participants who were representative of the entire population. The Directorate of Primary Education, the head teachers in the kindergartens as well as classroom teachers gave their permission for researchers to access the kindergartens and classes. Parents were notified about the nature of the study and consent was secured. Children were deemed competent research participants (Clark, 2007), able to agree to or refuse to participate in the research (Farell, 2005). Anonymity was ensured and pseudonyms have been used in this paper.

Specifically, twenty-seven 6-year-olds (14 boys and 13 girls) and thirty 9-year-olds (15 boys and 15 girls) participated in this research. The age of the pupils (6- and 9-year-olds) was thought to be important as (a) the sixyear-olds have yet to enter mainstream education whereas the nine-year-olds represent pupils who have experienced three years of teaching of Environmental Studies; (b) these ages represent two different cognitive stages (Piaget, 1969), and finally; (c) EfS forms part of the curriculum in kindergarten and primary classes. Moreover, building up a problem posing perspective takes less time when it starts with young students, who are by their very nature curious and have receptive minds, rather than with a mind that has already been programmed to see the world in terms of unidirectional cause and effect.

\section{Methods of Data Collection}

The students, as a whole group, were asked to draw a picture depicting the waste issue, as a way of representing it (Figure 1). Once they had finished their drawings, students were interviewed individually. Drawing was chosen as a method of collecting data as it is considered to be a good way for children to express their thoughts and feelings concerning the world around them (Arnheim, 1969; Van Manen, 1990). The interview was also chosen as a method of gathering information as it could easily be levelled up or down depending on the age of the interviewee (Cohen and Manion, 1994). 
All the interviews were transcribed verbatim and, the transcripts of the interviews constitute the data here. Initially, the students were called upon to describe how they represented the waste issue. Later, they were asked to define the term 'waste' using a photograph depicting overflowing garbage bins. Finally, every student was presented with images of various objects and asked to choose what they considered to be waste and to justify their choice. Amongst other questions, they were asked to respond to the following questions in an attempt to explore their abilities to pose the problem:

- What do you see in the picture?

- What is waste? Which of these do you think is waste? Why;

- Who produces waste? Why do people produce / make waste?

- Who or what is damaged by the waste and how?

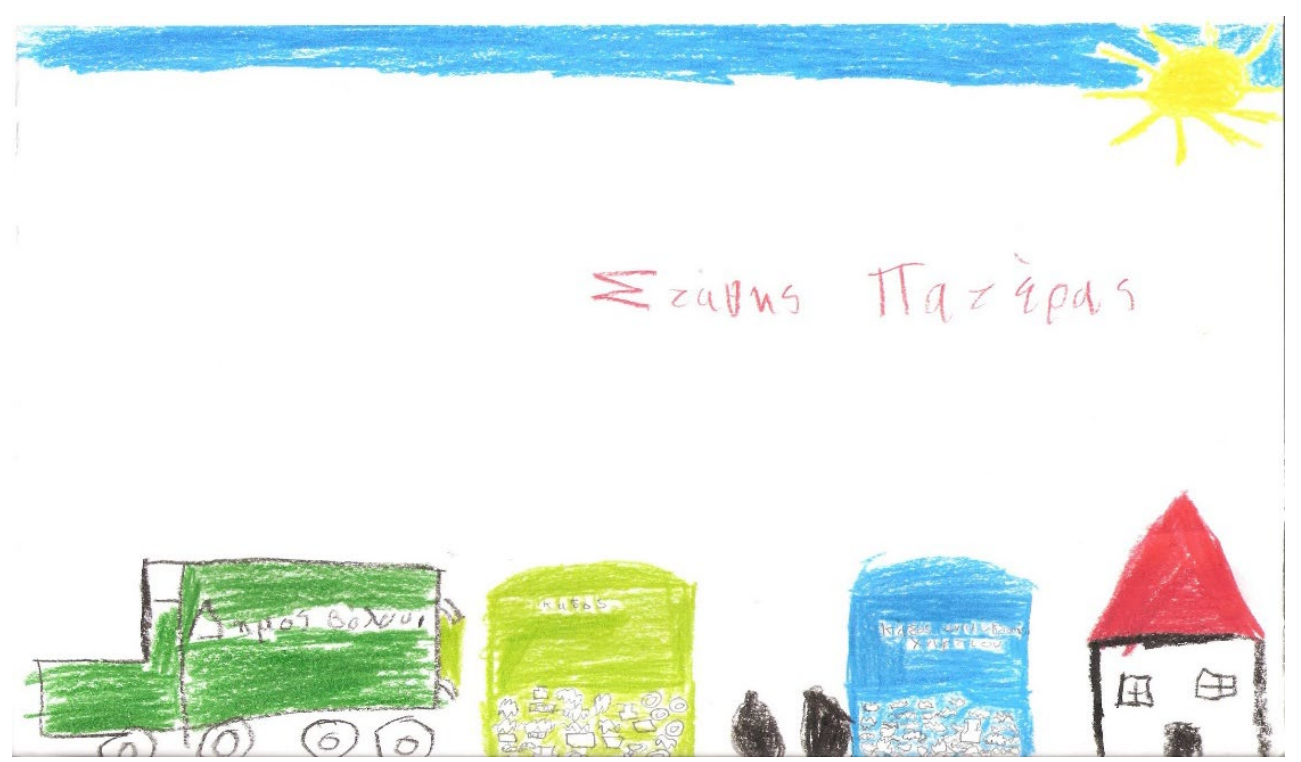

Figure 1. A 9-year-old's drawing (Garbage in and out of the bin)

\begin{abstract}
ANALYSIS
Maintaining reliability in coding necessitated the re-checking of criteria for data analyses. Therefore, a second researcher checked transcripts. Double coding was implemented to promote reliability between raters (Miles and Huberman, 1984). The inter-rater reliability coefficient was 0.80 . Along with common patterns that were noted, further consideration was given in order to determine significant differences.

Responses from children were analysed using content analysis with an inductive approach (Cohen and Manion, 1994).
\end{abstract}

\title{
RESULTS
}

The results emerging from the inductive analysis of the students' drawings and responses to the interview questions: "What do you see in the picture? What is waste? How is it created?" reveal the way the students define the waste problem. Table 2 shows that the older students give more answers in comparison to the younger ones (166 to 141 responses respectively) and more than half of the sample, connect humans to the act of producing waste. The students defined the environmental problem of waste by identifying its causes and its impacts. As Table 2 indicates, in their view, the waste problem originates from the fact that once people have used things ( 8 and 13 responses), they are useless to them (91 and 101 responses), so they throw them away (9 and 23 responses). In other words, only 8 and 13 students of the two age groups respectively connect waste with consumption. Some of them believe that waste is created only once rubbish is thrown outside of the bin (11 and 6 responses) or put in the bin ( 2 and 2 responses). Some of the students (13 and 7 responses) connect the idea of waste to the oldness of items. Some of their ideas (7 and 8 responses) reflect their incorrect conceptions of the waste issue. Only some of the third-graders ( 6 responses) connect the idea of waste to the things that they can not be recycled. The criteria set by both kindergarteners and third graders to define waste - its usefulness, appropriateness and oldness - concur with scientific criteria and results obtained from other studies (Dimitriou and Christidou, 2004, 2005). Unlike the studies of Dimitriou and Christidou (2004; 2005), which showed that children are unaware of the concepts of 
recycling and reuse when designating waste, the present study shows that children are aware of recycling and reuse, since they draw the sign of recycling on the bins (26.66\% of kindergarteners' drawings and $43.3 \%$ of third graders' drawings) and, many participants said that something is not garbage, when it can be reused $(13.7 \%$ of kindergarteners and $19.32 \%$ of third graders).

Typical definitions are as follows:

"A waste problem is when some kinds of things which are clean in the beginning, let's say, the container of yoghurt, at the beginning it's clean; it has yoghurt in it; people eat the yoghurt and throw the container away." (Anna, 9 years old)

"It's when we throw something in the bin because we do not need it anymore." (Anna, 6 years old)

"Those things that are very old so we throw them in the bin." (Peter, 9 years old)

"Anything we have used, put in bags and thrown away in bins." (Georgia, 9 years old)

"Because people do not want things - as these are no good any longer - they go and buy other things." (Kate, 6 years old)

"People buy milke from the supermarket and when it finishes they throw the carton in the dustbin because they do not need it anymore." (Nikos, 9 years old)

"People do not want their houses to stink. " (Athena, 6 years old)

"People make waste because they want to throw it out so as not to have useless materials in their houses." (Maria, 6 years old)

"They throw waste away to recycle it." (Kostas, 9 years old)

"The man creates waste when he uses things and he can not use them more." (Lili, 9 years old)

"We create waste when we do not have any bags and so we throw it away as it is." (V aso, 9 years old)

"People put waste in a bag and then throw it in the bin." (Xenofon, 6 years old).

Table 2. Definition of waste issue given by the students

\begin{tabular}{lcc}
\hline Definition & 6-year-olds (141 responses) & 9-year-old (166 responses) \\
\hline Useless (used, empty, damaged) & 91 & 101 \\
\hline Old & 13 & 7 \\
\hline We throw it & 9 & 23 \\
\hline Other (material, recyclable) & 7 & 8 \\
\hline Non-recyclable & 0 & 6 \\
\hline Have used it & 8 & 13 \\
\hline Thrown outside of a bin & 11 & 6 \\
\hline Put in a bin & 2 & 2 \\
\hline
\end{tabular}

\section{Effects}

As Table 3 shows half of the kindergarteners (18 responses) and one-third of the older students (26 responses) stress the negative impact of waste on people. Fewer students refer to the negative effects on the environment in general ( 7 and 12 responses) or on animals specifically (6 and 16 responses). Fewer participants refer to damage caused by waste to the air ( 2 and 6 responses) or to crops (1 and 9 responses).

Table 3. Effects of waste issue given by the students

\begin{tabular}{lcc}
\hline Effects & Six yrs (34 responses) & Nine yrs (69 responses) \\
\hline Damage involving people & 18 & 26 \\
\hline $\begin{array}{l}\text { Damage involving nature / } \\
\text { /environment/earth }\end{array}$ & 7 & 12 \\
\hline Damage involving animals & 6 & 16 \\
\hline Damage involving the air & 2 & 6 \\
\hline Damage involving crops & 1 & 9 \\
\hline
\end{tabular}

\section{Solutions}

Further study showed that the main solution suggested by half of the two age groups of the participants (17 and 13 responses respectively) is to "put waste into a bin". As shown in Table 4, the older students suggest, to a greater degree when compared with the younger students, the recycling/reusing ( 9 and 1 responses respectively) and consumption reduction (6 and 3 responses) methods of dealing with waste (Iliopoulou, 2016).

Table 4. Solutions given by the students

\begin{tabular}{lcc}
\hline Solutions & Six yrs (18 responses) & Nine yrs (30 responses) \\
\hline In the bin & 10 & 13 \\
\hline Reuse & 4 & 9 \\
\hline Reduce & 2 & 6 \\
\hline Other (Throw elsewhere, & 2 & 2 \\
\hline fly-tipping, punishment) & $\mathrm{T}$ & \\
\hline
\end{tabular}




\section{DISCUSSION}

The inductive analysis of students' drawings and their responses to the questions about their definition of the problem of waste showed that the majority of the participants are able to pose the problem, albeit in an incomplete way. Generally, according to their definition, the waste problem is created when people discard whatever is not useful to them. Few of them connect the waste issue to consumption or are aware of the reusing or recycling method of dealing with waste. Even fewer students, especially in the younger age group, suggest solutions other than just throwing garbage into a bin. The results show that those students, who know about reusing and recycling at the posing phase, suggest them as ways of reducing waste. It could probably be assumed that focusing more on improving the way students pose the problem - how they define and how they represent it - could affect their suggestions for addressing it. Of course, the third-graders pose the problem in a better way as they link waste production to consumption twice as often as the younger students did.

Some other interesting findings regarding the three research questions are as follows:

\section{How the Students Pose the Waste Problem}

Most students attribute waste with various characteristics, such as age, unsuitability and uselessness; results which concur with other research findings (Dimitriou and Christidou, 2004, 2005; Glazar, Vrtacnik and Bacnik, 1998). Moreover, some students connect waste to recyclable materials such as glass, plastic and paper and justify that people produce waste in order to recycle them, misunderstandings probably created when they were taught about recycling, as emerged from Palmer and her colleagues' study (2003). Furthermore, some students refer to food remains as waste, which indicates their ignorance of composting. Most students can not distinguish between "producing waste", and "discarding waste". This may reveal that they do not link waste production with its actual cause, which is consumption. This kind of confusion is frequent in everyday communication and is perhaps a result of the limited vocabulary the young students have (Chatzinikita and Christidou, 2001). Another reason could be the fact that the issue of waste in the student's books of the first three grades is introduced by providing pictures showing people throwing their garbage outside a bin. Although it is suggested that teachers cover the issue of waste in a more detailed way, it depends on the time available and the mood of each teacher as to whether they will expand on the topic or not. Moreover, a few students considered as "garbage" whatever was on the ground or outside the bin. Obviously, this result can be attributed to the students' daily experience with the problem of waste being identified as overflowing bins and scattered garbage on the streets.

Students understand the direct and indirect effects of waste on human health (getting sick, suffering allergies, etc.) and to a lesser extent on animals. This result agrees with the findings of the Dimitriou and Christidou' studies $(2004,2005)$. Fewer students refer to impacts on air, plants and nature in general, without knowing how. This is, perhaps, due to a lack of systematic teaching. Furthermore, they do not mention the impact on water and soil, contrary to what emerged from Dimitriou and Christidou's studies (2004, 2005); perhaps because those studies were conducted in a rural environment. Generally, students conceive the impact of waste in a homocentric way.

\section{How the Way Students Pose the Problem relates to their Solutions}

Concerning the solutions, students mainly suggest either the placement of garbage in bins or the collection of garbage which is outside of the bins; actions that do not constitute a reduction in waste. However, it results from their direct experience, where these actions are considered to be solutions to the problem. The three R's (recycle, reuse and reduce), which help in reducing the volume of waste are proposed to a lesser extent, a result which is congruent with the results of other surveys (Dimitriou and Christidou, 2004, 2005; Malandrakis, 2008). However, ignorance of the ways waste can be reduced may be connected to the students' inability to define their own contribution to solving the problem.

\section{How Problem-posing Abilities are Different due to Age?}

The results of the present study reveal the fact that there is a difference in the posing abilities of the two age groups in favour of the older students. Specifically, the third graders gave more responses in the posing phase compared to the kindergarteners. Moreover, they were more aware of the real causes, and the impacts of the waste, as well as ways of reducing it.

The present study had the limitation that it explored only the posing abilities that students could be competent of and not the impact of the implementation of a strategy for improving these abilities. Future research should cover this gap and explore the impact of a problem-posing strategy and how, once students have been taught various ways of defining and representing the problem, they may become more problem-solving competent. 


\section{IMPLICATIONS FOR EDUCATION}

As educators, we need to know how we can facilitate our students to break out of their mental models in order to gain new perspectives on environmental problems. If our ultimate goal is to help them become competent to solve the problems of their environment, we must be ready to examine the ill-defined issues surrounding problem recognition, definition, and representation (Pretz et al., 2003). As Priest (2009) believes, problem-posing intervention could enhance problem-solving competence. It is commonly recognised that the phase of problemposing in the problem-solving process is central to the finding of effective solutions. Educators who move too fast toward solutions, have somehow neglected this phase. Were more students able to pose a problem in a more complete way then more options of possible actions would be put forward. The use of visual representations and the sharing of ideas seem to have contributed to enhancing students' performance. When representation strategies are used, real discussions between students start and missing elements are added to complete the models held by students. In fact, when students visually represent the problem, they have the tendency to deliberate inwardly (about their way of framing the problem) and to monitor their understanding. Sharing their representations with their peers allows for constructive criticism of the participants' values and opinions of the problem (Jonassen 2000).

"Students empowered to define problems are able to influence the solutions that are considered and ultimately adopted" (Ebbin, 2011: 152). Gauthier and his colleagues suggest that environmental problems are extremely complex and require the development of critical thinking skills, higher order thinking skills, and more complex reflexive competencies (reflexivity and social processes of change).

\section{REFERENCES}

Arikan, E. E. and Unal, H. (2015). Investigation of Problem-Solving and Problem-Posing Abilities of SeventhGrade Students. Educational Sciences: Theory \& Practice 15(5), 1403-1416. https://doi.org/10.12738/estp.2015.5.2678

Arnheim, R. (1969). Visual Thinking. London: Faber \& Faber.

Barbier, P., Pruneau, D. and Freiman, V. (2007). Reframing a Research Project Design on How Six Graders Pose an Environmental Problem within a Romantic Understanding Imaginative Framework: An Hypothesis. Proceedings of the Second Annual Research Symposium on Imaginative education, Vancouver, BC.

Barbier, P., Freiman, V., Pruneau, D. and Langis, G. (2010). Emerging patterns of learning about environment by Grade 3 schoolchildren solving local sedimentation problem. Procedia Social and Behavioral Sciences, 2, 5693-5699. https://doi.org/10.1016/j.sbspro.2010.03.930

Bransford, J. D. and Stein, B. S. (1993). The Ideal Problem Solver. Centers for Teaching and Technology-Book Library. http:/ / digitalcommons.georgiasouthern.edu/ct2-library/46 (Accessed 8 August 2017).

Brown, S. I. and Walter, M. I. (2005).The art of problem posing (3rd ed.). Mahwah, NJ: Lawrence Erlbaum Associates. https://doi.org/10.4324/9781410611833

Cai, J. (1998). An investigation of U.S. and Chinese students' mathematical problem posing and problem solving. Mathematics Education Research Journal, 10, 37-50. https://doi.org/10.1007/BF03217121

Cai, J. and Hwang, S. (2002). Generalized and generative thinking in US. and Chinese students' mathematical problem solving and problem posing. The Journal of Mathematical Behavior, 21, 401-421. https:// doi.org/10.1016/S0732-3123(02)00142-6

Cankoy, O. and Darbaz, S. (2010). Problem kurma temelli problem çözme öğretiminin problemi anlama başarısına etkisi. Hacettepe Üniversitesi Eğitim Fakültesi Dergisi, 38, 11-24.

Chatzinikita, V. and Christidou, V. (2001).Students' practical-experiential learning: General characteristics. In Didactics of Science, edited by K. Dimopoulos, and V. Chatzinikita, 153-188. Patra: Hellenic Open University (in Greek).

Clark, A. (2007). A Hundred Ways of Listening. Gathering Children's Perspectives of Their Early Childhood Environment. Young Children, 62(3), 76-81.

Cohen, L. and Manion, L. (1994). Educational Research Methodology. Athens: Metaixmio.

Crespo, S. (2003). Learning to pose mathematical problems: Exploring changes in preservice teachers' practices. Educational Studies in Mathematics, 52, 243-270. https://doi.org/10.1023/A:1024364304664

CVRB. (n.d.). Environmental Education Teaching Strategy - Environmental Problem Solving Environmental Education Teaching Strategy. Water Monitoring Youth Portal. http://www.g3e-ewag.ca/documents/fiches_pedagogiques/fiche7_ ang.pdf (Accessed 9 August 2017).

DEPPS. (2001). Cross Curriculum Framework and Curricula of Compulsory Education. Athens: Ministry of Education. (in Greek). 
DEPPS. (2003a). Cross Curriculum Framework for Kindergarten. http://www.pischools.gr/content/index.php?lesson_id=300\&ep=367 (in Greek) (Accessed 23 June 2017).

DEPPS. (2003b). Cross-single framework curricula and analytical compulsory education curricula. Athens: Ministry of Education-III, Gazette 304B / 13-03-2003. http:/ / www.pi-schools.gr/programs/depps/ (in Greek) (Accessed 22 June 2017).

Dimopoulou, M., Zobolas, T., Babila, H., Skanavi, K., Frantzi, A. and Hatzimihael,M. (2006a).Study of Environment B' Grade. Teacher's Book. Athens: Ministry of Education. (in Greek).

Dimopoulou, M., Zobolas, T., Babila, H., Skanavi, K., Frantzi, A. and Hatzimihael,M. (2006b). Study of Environment $B^{\prime}$ Grade. Teacher's Book. Athens: Ministry of Education. (in Greek)

Ebbin, S. A. (2011).The Problem with Problem Definition: Mapping the Discursive Terrain of Conservation in Two Pacific Salmon Management Regimes. Society \& Natural Resources, 24(2), 148-164. https://doi.org/10.1080/08941920903468639

Elias, M. J., Branden-Muller, L. R. and Sayette, M. A. (1991). Teaching the foundations of social decision making and problem solving in the elementary school. In Teaching decision making to adolescents, edited by J. Baron and R.V. Brown, 161-184. Hillsdale, NJ: Lawrence Erlbaum Associates.

Ellerton, N. F. (1986). Children's made-up mathematics problems: A new perspective on talented mathematicians. Educational Studies in Mathematics, 17, 261-271. https://doi.org/10.1007/BF00305073

Ellis, S. and Siegler, R. S. (1994). Development of problem solving. In Thinking and problem solving. Handbook of perception and cognition (2nd ed.), edited by R. J. Sternberg, 333-367. San Diego, CA: Academic Press. https://doi.org/10.1016/B978-0-08-057299-4.50017-7

English, L. D. (1997).The development of fifth-grade children's problem-posing abilities. Educational Studies in Mathematics, 34(3), 183-217. https:/ / doi.org/10.1023/A:1002963618035

Farell, A. (2005). Ethical Research with Children. Berkshire: Open University Press.

Freire, P. (1970). Pedagogy of the oppressed. New York, NY: The Continuum Publishing Corporation.

Glazar, S. A., Vrtacnik, M. and Bacnik, A. (1998). Primary school children's understanding of municipal waste processing. Environmental Education Research, 4(3), 299-308. https://doi.org/10.1080/1350462980040305

Green, A. (1993).Creativity in public relations. London: Kogan Page.

Gregg, M. (1997). Problem posing from maps: Utilizing understanding. Journal of Geography, 96(5), 250-256. https://doi.org/10.1080/00221349708978799

Grundmeier, T. A. (2003).The effects of providing mathematical problem posing experiences for K-8 pre-service teachers: Investigating teachers beliefs and characteristics of posed problems (Unpublished doctoral dissertation). University of New Hampshire, Durham, NH. Hasselblad

Harris, R. (1998). Introduction to Decision Making, Virtual Salt. http:/ /www.virtualsalt.com/crebook5.htm (Accessed 9 August 2017).

Hauslein, P. L. and Smith, M. U. (1994). Knowledge structures and successful problem solving. In Toward a cognitive science perspective for scientific problem sovling, NARST Monograph No. 6, edited by D.R. Lavoie. Manhattan, Kansas: National Association for Research in Science Teaching.

Hayes, S. C. (1989). Rule-governed behavior: Cognition, contingencies, and instructional control. New York: Plenum. Publication Topic: ACT: Conceptual. https://doi.org/10.1007/978-1-4757-0447-1

Iliopoulou, I. (2011). Preschool and First Grade Children's Conceptions of V arious Dimensions of Environmental Issues Such as: Forest, Waste, Air and Sea Pollution, Water and Electricity Consumption. PhD dissertation, University of Thessaly, Greece (in Greek).

Iliopoulou, I. (2016). How young children think they can act for the environment: the case of forest and waste. Education, 3-13. https://doi.org/10.1080/03004279.2016.1236829

Iliopoulou, I. (2018). Children's thinking about environmental issues. Educational Research. https://doi.org/10.1080/00131881.2018.1453753

Jonassen, D. H. (2000). Toward a design theory of problem solving. Educational Technology Research and Development, 48(4), 63-85. https:// doi.org/10.1007/BF02300500

Jones, M. D. (1995).The thinker's toolkit. Fourteen skills for making smarter decisions in business and in life. Toronto: Random House.

Kokkotas, P., Alexopoulos, D., Malamitsi, A., Mantas, C., Mooring, M. and Panagiotaki, P. (.2006). Environmental Studies C Grade. Teacher's Book. Athens: Ministry of Education OEDB (in Greek).

Kotovsky, K., Hayes, J. R. and Simon, H. A. (1985). Why are some problems hard? Evidence from the Tower of Hanoi. Cognitive Psychology, 17, 248-294. https://doi.org/10.1016/0010-0285(85)90009-X

Leung, S. K. and Silver, E. A. (1997). The role of task format, mathematics knowledge, and creative thinking on the arithmetic problem posing of prospective elementary school teachers. Mathematics Education Research Journal, 9(1), 5-24. https://doi.org/10.1007/BF03217299 
Levav-Waynberg, A. and Leikin, R. (2009). Multiple solutions for a problem: A tool for evaluation of mathematical thinking in geometry. In Proceedings of Sixth Conference of European Research in Mathematics Education, edited by V. Durand-Guerrier, S. Soury- Lavergne, and F. Arzarello, 776-785. Lyon, France: CERME6.

Malandrakis, G. (2008). Children's Understandings Related to Hazardous Household Items and Waste. Environmental Education Research, 14(5), 579-601. https:/ / doi.org/10.1080/13504620802465046

Michalko, M. (1991). Thinkertoys. A handbook for business creativity for the 90s. Berkeley, California, Ten Speed Press.

Miles, M. B. and Huberman, A. M. (1984) Qualitative Data Analysis: A Sourcebook of New Methods. Thousand Oaks, CA: Sage.

Palmer, J. A., Grodzinska-Jurczak, M. and Suggate, J. (2003). Thinking about waste: Development of English and Polish children's understanding of concepts related to waste management. European Early Childhood Education Research Journal, 11(2), 117-39. https:/ / doi.org/10.1080/13502930385209201

Piaget, J. (1969). The Child's Conception of the World. London: Kegan Paul.

Pittalis, M., Christou, C., Mousoulides, N. and Pitta-Pantazi, D. (2004). A structural model for problem posing. Proceedings of the 28th Conference of the International Group for the Psychology of Mathematics Education, 4, 49-56.

Plakitsi, C., Kontogianni, A., Spiratou, E. and Manoli, V. (2006a). Study of Environment A' Grade. Athens:Ministry of Education. (in Greek)

Plakitsi, C., Kontogianni, A., Spiratou, E. and Manoli, V. (2006b). Study of Environment A' Grade Excercise book. Athens: Ministry of Education. (in Greek)

Poya, G. (1957). How to solve it (2nd ed.). New York: Doubleday.

Pretz, E. J., Naples, J. A. and Sternberg, J. R. (2003). Recognizing, Defining, and Representing Problems. In The Psychology of problem solving, edited by J. E. Davidson and R. J.Sternberg. USA: Cambridge University Press.

Priest, J. D. (2009). A problem-posing intervention in the development of problem-solving competence of underachieving, middle-year students. Thesis Faculty of Education, Queensland University of Technology, Brisbane.

Proulx, L. P. (1999). La r'esolution de probl'emes en enseignement. Cadre r' ef'erentiel et outils de formation [Problem solving in teaching. Conceptual framework and training tools]. Paris: De Boeck \& Larcier.

Pruneau, D., Freiman, V., Barbier, P. and Langis, J. (2009). Helping Young Students to Better Pose an Environmental Problem. Applied Environmental Education and Communication, 8, $105-113$. https://doi.org/10.1080/15330150903133678

Pruneau, D., Gravel, H., Courque, W. and Langis, L. (2003). Experimentation with socioconstructivist process for climate change education. Environmental Education Research, 9(4), $429-446$. https:/ / doi.org/10.1080/1350462032000126096

Pruneau, D., Liboiron, L.,Vrain, E., Gravel, H. Bourque, W. and Langis, J. (2001). People's ideas about climate change: a source of inspiration for the creation of educational programs. Canadian Journal of Environmental Education, 6, 121-138.

Silver, E. A. (1997). Fostering creativity through instruction rich in mathematical problem solving and problem posing. ZDM, 29(3), 75-80. https://doi.org/10.1007/s11858-997-0003-x

Silver, E. A. and Cai, J. (1996). An analysis of arithmetic problem posing by middle school students. Journal for Research in Mathematics Education, 27, 521-539. https:// doi.org/10.2307/749846

Sternberg, R. J. (1986). Critical thinking: Its nature, measurement, and improvement. http:/ / eric.ed.gov/PDFS/ED272882.pdf (Accessed 12 June 2012)

Stickles, P. R. (2006). An analysis of secondary and middle school teacher's mathematicalproblem posing (Unpublished Doctoral Dissertation). Available from ProOuest Dissertations and Theses database. (UMI No. 3219902)

Stoyanova, E. (2000). Empowering students' problem solving via problem posing. Australian Mathematics Teacher, 25(10), 33-37.

Stoyanova, E. and Ellerton, N. F. (1996). A framework for research into student's problem posing in school mathematics. Mel Bourne, Australia: Mathematics Education Research Group of Australia.

UNESCO (1998). Citizenship Education for the 21st Century. France: Paris UNESCO

UNESCO (2010). Citizenship Education. http://www.unesco.org/education/tlsf/mods/theme_b/interact/ mod07task03/appendix.htm (Accessed 4 July 2017).

Van Manen, M. (1990). Researching lived experience: Human science for an action sensitive pedagogy. Abany, NY: State University of New York Press.

Verschaffel, L., Van Dooren, W., Chen, L. and Stessens, K. (2009). The relationship between posing and solving division-with-remainder problems among Flemish upper elementary school children. In Words and worlds: Modeling verbal descriptions of situations, edited by L. Verschaffel, B. Greer, W. Van Dooren, and S. Mukhopadhyay. Rotterdam: Sense Publishers.

Yaman, S. and Dede, Y. (2005). Matematik ve fen eğitiminde problem kurma uygulamalari. OMÜ Ĕgitim Fakültesi Dergisi, 20, 1-11. 